\title{
Changes in bone metabolic parameters following oral calcium supplementation in an adult patient with vitamin D-dependent rickets type $2 \mathrm{~A}$
}

\author{
Yuka Kinoshita $^{1)}$, Nobuaki Ito ${ }^{1)}$, Noriko Makita ${ }^{1)}$, Masaomi Nangaku ${ }^{1)}$ and Seiji Fukumoto ${ }^{2)}$ \\ 1) Division of Nephrology \& Endocrinology, Department of Medicine, the University of Tokyo Hospital, Tokyo, Japan \\ 2) Fujii Memorial Institute of Medical Sciences, Tokushima University, Tokushima, Japan
}

\begin{abstract}
Vitamin D-dependent rickets type 2A(VDDR2A) is a rare inherited disorder with decreased tissue responsiveness to 1,25 -dihydroxyvitamin $\mathrm{D}\left[1,25(\mathrm{OH})_{2} \mathrm{D}\right]$, caused by loss of function mutations in the vitamin $\mathrm{D}$ receptor $(V D R)$ gene. Approximately 50 types of mutations have been identified so far that change amino acids in either the N-terminal DNA binding domain (DBD) or the C-terminal ligand binding domain (LBD) of the VDR protein. The degree of responsiveness to $1,25(\mathrm{OH})_{2} \mathrm{D}$ varies between patients with VDDR2A, which may depend on their residual VDR function. In this report, we describe a female patient with VDDR2A caused by an early stop codon (R30X) in the VDR gene that resulted in a severely truncated VDR protein. She developed alopecia and bowed legs within a year after birth and was diagnosed with rickets at the age of 2 . She had been treated with active vitamin D and oral calcium supplementation until 22 years of age, when she developed secondary hyperparathyroidism and high bone turnover. The genetic diagnosis of VDDR2A promoted the discontinuation of active vitamin $\mathrm{D}$ treatment in favor of monotherapy with oral calcium supplementation. We observed amelioration of the secondary hyperparathyroidism and normalization of bone metabolic parameters within 6 years.
\end{abstract}

Key words: Rickets, Vitamin D receptor, Calcium, Hyperparathyroidism

RICKETS is a childhood disease characterized by skeletal deformities, such as bowed legs and short stature, caused by impaired mineralization of bone matrix and disorganized growth plates. The equivalent disease in adults is osteomalacia, which commonly causes back and hip pain, muscle weakness, and bone fragility [1]. Rickets and osteomalacia are typically caused by a lack of sufficient vitamin $\mathrm{D}$, calcium, or phosphate [1, 2]. Nutritional deficiency is the most common cause of rickets worldwide [3]; however, there are also genetic etiologies that can result in abnormal calcium and phosphate metabolism $[4,5]$. Vitamin D-dependent rickets type 2A (VDDR2A) (OMIM\#277440), also known as hereditary vitamin D-resistant rickets (HVDRR), is a rare inherited disorder with decreased tissue responsiveness to 1,25-dihydroxyvitamin $\mathrm{D}\left[1,25(\mathrm{OH})_{2} \mathrm{D}\right]$

Submitted Dec. 5, 2016; Accepted Feb. 16, 2017 as EJ16-0583 Released online in J-STAGE as advance publication Mar. 31, 2017 Correspondence to: Yuka Kinoshita, M.D., Ph.D., Division of Nephrology \& Endocrinology, Department of Medicine, the University of Tokyo Hospital, 7-3-1 Hongo, Bunkyo-ku, Tokyo 113-8655, Japan. E-mail: kudou-tky@umin.ac.jp caused by loss-of-function mutations in the vitamin $\mathrm{D}$ receptor $(V D R)$ gene $[6,7]$.

VDR is one of several nuclear transcription factors composed of an N-terminal DNA binding domain (DBD) and a C-terminal ligand binding domain (LBD) [8]. VDR is nearly ubiquitously expressed in cells and regulates as much as $3 \%$ of all human genes [9]. VDR forms a heterodimer with the retinoid $\mathrm{X}$ receptor (RXR) in the nucleus and regulates transcription of target genes by binding to their promoter regions [10-12]. Although vitamin D is essential for calcium and bone homeostasis, in vivo studies using total or tissue-specific $V D R$ knockout or $V D R$ transgenic animals have suggested more diverse functions of the VDR-vitamin D system in the body [9].

In patients with VDDR2A, approximately 50 kinds of mutations have been identified that change amino acids in both the DBD and the LBD of the VDR protein [7]. The degree of responsiveness to $1,25(\mathrm{OH})_{2} \mathrm{D}$ varies between patients, and some may respond to high doses of active vitamin D. Additionally, some patients develop total or partial alopecia in childhood. 
An association between disease severity and alopecia has been described, and patients with mutations in the N-terminal DBD are more likely to develop total alopecia $[13,14]$. Although a high-calcium rescue diet has been shown to normalize serum calcium levels and prevent the development of secondary hyperparathyroidism and skeletal abnormalities in $V D R$-null mice, it was not able to reverse alopecia [15].

In this report, we describe an adult patient with VDDR2A caused by an early stop codon in the VDR gene. When genetic diagnosis clarified the etiology of her rickets at the age of 22 , we speculated that active vitamin $\mathrm{D}$ treatment was ineffective in correcting her hypocalcemia because VDR function may have been completely lost. Therefore, we discontinued active vitamin D treatment and started to treat her with oral calcium supplementation alone. Significant changes in her bone metabolic parameters were observed over 6 years.

\section{Subjects and Methods}

\section{Subjects}

A 22-year-old female patient was introduced to our hospital in order to clarify the etiology of her hypocalcemia and childhood rickets. She was born by cesarean section at 38 weeks. She had no family history of rickets, but her parents were second cousins. Her birth weight was 3,000 g, and her birth length was $48 \mathrm{~cm}$. She developed alopecia at the age of 10 months and bowed legs at the age of 14 months. She was diagnosed with rickets at the age of 2 when her body height was $74.2 \mathrm{~cm}(-3.3 \mathrm{SD})$ and her body weight was 8.2 $\mathrm{kg}(-2.6 \mathrm{SD})$. A bone radiograph demonstrated bowed legs, widened growth plates, and cupping and fraying of metaphyses, which are compatible with a diagnosis of rickets. Laboratory data showed hypocalcemia, hypophosphatemia, and elevated serum $1,25(\mathrm{OH})_{2} \mathrm{D}$.
Treatment with alfacalcidol and calcium lactate was initiated. She had normal psychomotor development, but her height and weight remained 2.5 SD below the mean. At the age of 22, her body height was $136 \mathrm{~cm}$ and her body weight was $37 \mathrm{~kg}$.

Her initial evaluation at our hospital revealed a low corrected calcium level of $8.3 \mathrm{mg} / \mathrm{dL}$ (reference range, 8.8-10.1), a low phosphate level of $2.3 \mathrm{mg} / \mathrm{dL}$ (reference range, 2.7-4.6), and an elevated serum alkaline phosphatase (ALP) level of $662 \mathrm{U} / \mathrm{L}$ (reference range, 106-332). She was taking $54 \mu \mathrm{g}$ of alfacalcidol, $18 \mu \mathrm{g}$ of calcitriol and $3.5 \mathrm{~g}$ of calcium lactate $(455 \mathrm{mg}$ of elemental calcium) per day. The serum $1,25(\mathrm{OH})_{2} \mathrm{D}$ level was significantly elevated at $1,290 \mathrm{pg} / \mathrm{mL}$ (reference range, 20-60), and the serum 25-hydroxyvita$\min \mathrm{D}[25(\mathrm{OH}) \mathrm{D}]$ level was low at $6 \mathrm{ng} / \mathrm{mL}$ (reference range, 7-41). The serum intact PTH level was elevated at $239 \mathrm{pg} / \mathrm{mL}$ (reference range, 10-65), along with significantly elevated bone turnover markers (Table 1). An ultrasound of the neck revealed an enlargement of three parathyroid glands. Bone mineral density (BMD) at lumber spine measured by dual energy X-ray absorptiometry was $0.918 \mathrm{~g} / \mathrm{cm}^{3}$, which corresponded to $82 \%$ of the YAM value and a T-score of -1.7. The serum FGF23 level was below the limit of detection, which was evaluated using an FGF23 ELISA KIT (Kainos, Tokyo, Japan) that could detect only full-length FGF23 [16]. These clinical findings indicated a likely diagnosis of VDDR2A.

\section{Analysis of the VDR gene}

This study was approved by the institutional review board of the University of Tokyo and written informed consent was obtained from the patient.

Genomic DNA was extracted from the peripheral blood of the patient using the QIAamp DNA Blood Mini Kit (QIAGEN, Tokyo, Japan). Coding exons and

Table 1 Laboratory data and bone mineral density of our patient

\begin{tabular}{lrrrrrr}
\hline Age (years) & \multicolumn{1}{c}{22} & 23 & 24 & 25 & 26 & \multicolumn{1}{c}{28} \\
\hline BAP $(\mu \mathrm{g} / \mathrm{L}, 2.9-14.5)$ & $97.5^{*}$ & 41.4 & 37.3 & 36.1 & 25.6 & 13.0 \\
TRACP-5b (mU/dL, 120-420) & 1,490 & 870 & NR & 662 & 666 & 423 \\
$1,25(\mathrm{OH})_{2} \mathrm{D}(\mathrm{pg} / \mathrm{mL}, 20-60)$ & 1,290 & 128 & 88.9 & $\mathrm{NR}$ & $\mathrm{NR}$ & 91.8 \\
Aldosterone $(\mathrm{pg} / \mathrm{mL}, 35.7-240)$ & 160 & $\mathrm{NR}$ & 356 & 346 & $\mathrm{NR}$ & 323 \\
Plasma renin activity $(\mathrm{ng} / \mathrm{mL} / \mathrm{hr}, 0.3-2.9)$ & 5.2 & $\mathrm{NR}$ & 5.8 & 6.5 & $\mathrm{NR}$ & 3.3 \\
$\mathrm{~K}(\mathrm{mmol} / \mathrm{L}, 3.6-4.8)$ & 3.6 & 3.8 & 3.4 & 3.2 & 3.8 & 3.8 \\
eGFR $\left(\mathrm{mL} / \mathrm{min} / 1.73 \mathrm{~m}^{2}\right)$ & 165.4 & 150.5 & 156.8 & 136.2 & 120.0 & 105.9 \\
BMD L2-L4 $\left(\mathrm{g} / \mathrm{cm}^{3}\right)$ & 0.918 & $\mathrm{NR}$ & $\mathrm{NR}$ & 1.135 & $\mathrm{NR}$ & 1.289 \\
\hline
\end{tabular}

Units and reference ranges are shown in parentheses after items; NR, not recorded; ${ }^{*}$ The unit and the reference range of BAP at this point is $\mathrm{U} / \mathrm{L}$ and 9.6-35.4. 
exon-intron junctions of the $V D R$ gene were amplified by PCR using the SapphireAmp ${ }^{\circledR}$ Fast PCR Master Mix (TAKARA BIO, Shiga, Japan). PCR conditions were as follows: 1 minute at $94{ }^{\circ} \mathrm{C}$, followed by 35 cycles of 5 seconds at $98^{\circ} \mathrm{C}, 5$ seconds at $58^{\circ} \mathrm{C}$, and 5 seconds at $72{ }^{\circ} \mathrm{C}$, with a final extension for 3 minutes at $72{ }^{\circ} \mathrm{C}$. Primer sequences can be obtained upon request. PCR products were purified using the NucleoSpin ${ }^{\circledR}$ Gel and PCR Clean-up (Macherey-Nagel, Duren, Germany) and were directly sequenced with dye-deoxy termination cycle sequencing using the same primers as those used for the PCR reaction.

\section{Analysis of the VDR $m R N A$}

RNA was extracted from the peripheral blood of the patient, along with the normal controls, using the NucleoSpin ${ }^{\circledR}$ RNA Blood (Macherey-Nagel, Duren, Germany), and it was transcribed to cDNA using the PrimeScript ${ }^{\circledR}$ RT Master Mix (TAKARA BIO, Shiga, Japan). A 150 base-pair segment of $V D R$ cDNA and a 100 base-pair segment of GAPDH cDNA were amplified using the SapphireAmp ${ }^{\circledR}$ Fast PCR Master Mix (TAKARA BIO, Shiga, Japan). The primer sets were 5'-tctctttgggaagcctttgg-3' and 5'-gttccggtcaaagtctccag-3' for $V D R$ and 5'-tggcaccgtcaaggetgaga-3' and 5'-ccagcatcgecccacttgat-3' for GAPDH. Conventional
PCR conditions were as follows: 1 minute at $94{ }^{\circ} \mathrm{C}$, followed by 35 cycles of 5 seconds at $98{ }^{\circ} \mathrm{C}, 5 \mathrm{sec}$ onds at $58{ }^{\circ} \mathrm{C}$, and 5 seconds at $72{ }^{\circ} \mathrm{C}$, with a final extension for 3 minutes at $72{ }^{\circ} \mathrm{C}$. PCR products were electrophoresed on a $1 \%$ agarose gel containing ethidium bromide, and then visualized with UV light. For quantitative analysis of $V D R$ mRNA, real-time PCR was performed using the StepOnePlus Real-Time PCR system (Applied Biosystems, Thermo Fisher Scientific K.K., Kanagawa, Japan) using SYBR Premix Ex Taq II (TAKARA BIO, Shiga, Japan) and the same primers as those used for the conventional RT-PCR. The expression levels of $V D R$ and GAPDH mRNA were interpolated from the standard curves.

\section{Results}

\section{Analysis of the VDR gene and VDR mRNA}

We identified a homozygous nonsense mutation in the $V D R$ gene of the patient (c.88C > T, p.R30X) (Fig. 1A). This mutation has previously been reported in patients with VDDR2A [17-19]. RT-PCR detected $V D R$ cDNA in the peripheral blood of the patient and controls (Fig. 1B). The expression level of $V D R$ mRNA in peripheral blood of the patient was higher than that in controls (Table 2).
A

$$
\begin{aligned}
& \text { Arg30Ter/Arg30Ter } \\
& \text { AGACTGAGCCA }
\end{aligned}
$$

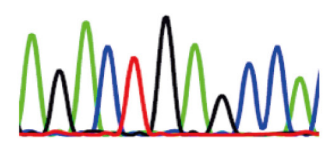

B

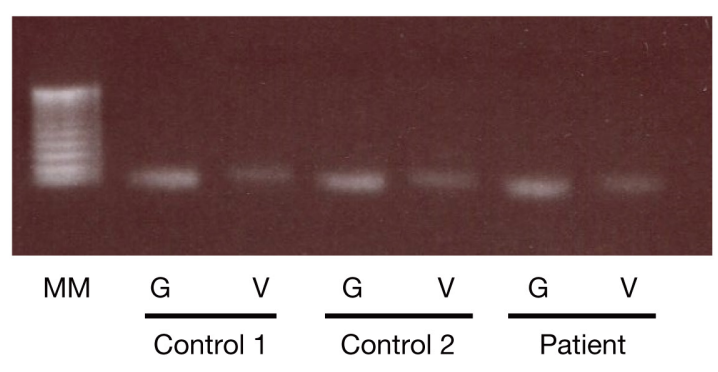

Fig. 1 A) The patient encoded a homozygous nonsense mutation in the $V D R$ gene (c.88C $>$ T, p.R30X). B) RT-PCR showed $V D R$ mRNA in peripheral blood of the patient and controls. MM, molecular marker; G, GAPDH; V, VDR.

Table 2 Real-time PCR analysis of $V D R$ mRNA

\begin{tabular}{lccc}
\hline & Control 1 & Control 2 & Patient \\
\hline Ct value of $G A P D H^{\#}$ & $20.6 \pm 0.0$ & $20.8 \pm 0.1$ & $20.7 \pm 0.1$ \\
Ct value of $V D R^{\#}$ & $29.5 \pm 0.2$ & $29.4 \pm 0.1$ & $28.0 \pm 0.1$ \\
$V D R / G A P D H$ mRNA & 1.0 & 1.1 & 2.8 \\
\hline \# & The Ct values of GAPDH and $V D R$ are shown as means $\pm \mathrm{SD}(\mathrm{N}=2) .{ }^{*}$ The $V D R / G A P D H$ \\
mRNA is shown as the ratio of each value to that of Control 1.
\end{tabular}




\section{Clinical course}

Due to an early premature stop codon in the VDR gene of the patient, we speculated that her VDR function was completely lost and that active vitamin D would be ineffective in correcting her hypocalcemia. Therefore, we decided to treat her with oral calcium alone. As she had initially been treated with calcium lactate (3.5 g/day), alfacalcidol (54 $\mu \mathrm{g} /$ day), and calcitriol (18 $\mu \mathrm{g} /$ day), we stopped both the alfacalcidol and calcitriol and increased the dose of calcium lactate to $5 \mathrm{~g} /$ day. Since then, she has been treated with 5-6 g/day calcium lactate. Fig. 2 and Table 1 show changes in laboratory data and BMD over 6 years. Her serum calcium and phosphate levels fluctuated around the lower limit of the reference range, with an overall upward trend. Her serum ALP and intact PTH levels were significantly reduced over 6 years and nearly normalized at the age of 28 (Fig. 2). Coincidental with the improvement in secondary hyperparathyroidism, an ultrasound revealed a reduction in size of her parathyroid glands. Urine analyses with random urine samples showed that the urine calcium/creatinine ratio ( $\mathrm{uCa} / \mathrm{Cre})$ and the ratio of tubular maximum reabsorption of phosphate to GFR (TmP/GFR) moved in parallel with serum calcium and serum phosphate, respectively (Fig. 3).

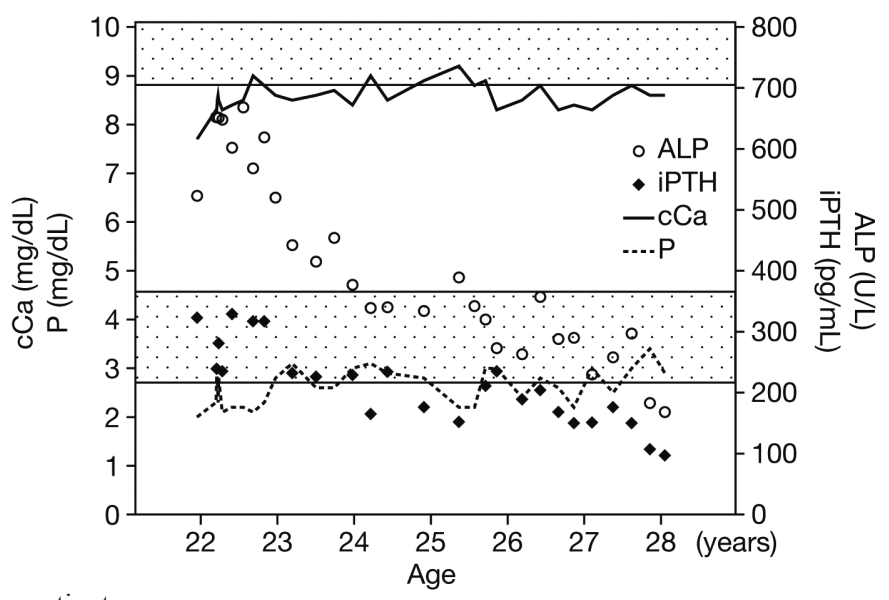

Fig. 2 The clinical course of our patient

The dotted area represents the reference range of serum corrected calcium (cCa) and phosphate (P). Serum cCa and P levels fluctuated around the lower limit of the reference range with an overall upward trend. Concurrently, serum ALP and intact PTH levels were significantly reduced over 6 years.

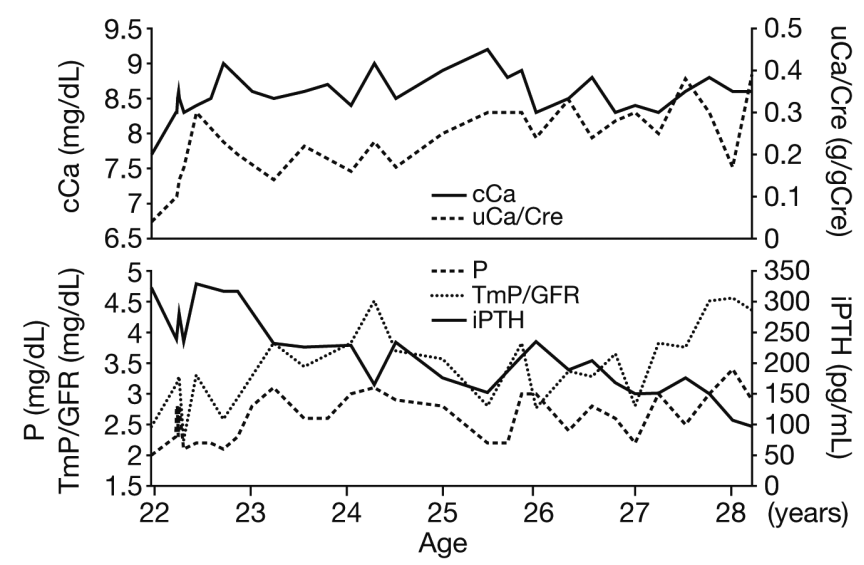

Fig. 3 Serum and urine parameters of calcium $(\mathrm{Ca})$ and phosphate $(\mathrm{P})$ metabolism in our patient

The serum corrected $\mathrm{Ca}(\mathrm{cCa})$ and urine $\mathrm{Ca} /$ creatinine ratio $(\mathrm{uCa} / \mathrm{Cre})$ moved in parallel with an upward trend (upper panel). As intact PTH decreased, serum P and the ratio of tubular maximum reabsorption of phosphate to GFR (TmP/GFR) moved in parallel, with an upward trend (lower panel). 
Both the bone formation marker, bone alkaline phosphatase (BAP), and the bone resorption marker, tartrate-resistant acid phosphatase 5b (TRACP-5b), were extremely elevated at the age of 22 . These gradually decreased nearly to the reference range, with a concurrent increase in BMD (Table 1). Serum $1,25(\mathrm{OH})_{2} \mathrm{D}$ declined after the cessation of active vitamin $\mathrm{D}$ treatment but remained higher than normal, and the estimated glomerular filtration rate (eGFR) gradually decreased over 6 years.

The patient displayed elevated plasma renin activity and serum aldosterone, along with occasional mild hypokalemia, which suggested upregulation of the reninangiotensin-aldosterone system (Table 1). However, an ambulatory blood pressure monitoring (ABPM) showed no signs of systemic hypertension and an echocardiogram did not detect left ventricular hypertrophy.

\section{Discussion}

We present here an adult patient with VDDR2A whose bone metabolic parameters had been observed over 6 years. In vivo analyses have shown that a high calcium diet can improve calcium homeostasis and skeletal abnormalities in $V D R$-null mice $[15,20]$; however, little is known about its effects on bone metabolism in adult patients with VDDR2A. The VDRnull mice that were placed on the high calcium, high phosphate, and high lactose rescue diet maintained normal calcium and phosphate levels and did not develop rickets [15]. Although a rescue diet could not prevent alopecia in $V D R$-null mice, PTH levels and parathyroid glandular size of $V D R$-null mice on the rescue diet were not different from those of wild-type littermates [15]. Oral calcium supplementation ameliorated secondary hyperparathyroidism in our patient and nearly normalized her bone metabolism over 6 years. The clinical course of our patient and the $V D R$-null mice suggests that serum calcium plays a key role in the pathogenesis of hyperparathyroidism when the VDR-vitamin D system is absent. It is known that intestinal calcium absorption consists of both a passive paracellular transport and a vitamin D-dependent active transcellular transport [21]. Thus, increasing oral calcium intake may be effective in promoting paracellular transport and maintaining normal calcium homeostasis in patients with VDDR2A. Although the efficacy of high doses of $1,25(\mathrm{OH})_{2} \mathrm{D}$ has been reported in some patients with VDDR2A, the treatment courses of our patient and a 3-year-old patient with a homozygous R73X mutation [22] suggest that monotherapy with oral calcium supplementation should be considered in patients with deleterious VDR mutations. Urine analyses with random urine samples from our patient showed high urine calcium excretion relative to serum calcium. This relative hypercalciuria, which has also been shown in $V D R$-null mice on a rescue diet [23], is probably due to disturbed calcium reabsorption in the distal tubules, which are mainly controlled by PTH and $1,25(\mathrm{OH})_{2} \mathrm{D}$ [24].

In addition to our case, three different families with R30X mutations in the $V D R$ gene have been reported [17-19]. The first case is a 12-year-old boy in Brazil whose asymptomatic parents were first cousins [17]. The second case is a 2-year-old boy from nonconsanguineous French-Canadian parents [18]. The third case is a 2-year-old girl with a mother from Indonesia and a father from the Czech Republic [19]. The first two cases are homozygous for the R30X mutation, and the last is heterozygous for the R30X mutation and a 3-bp in-frame deletion that results in the deletion of lysine 246. All three patients developed total alopecia within a few months after birth, and showed severe early-onset rickets. They also presented with secondary hyperparathyroidism at referral. They were treated with $3 \mathrm{~g}$ of elemental calcium and 3-30 $\mu \mathrm{g}$ calcitriol, which partially improved their laboratory data and bone deformities. However, their alopecia could not be reversed.

The loss of function of VDR in our patient seems to be the direct result of a truncated VDR protein and not secondary to nonsense-mediated mRNA decay. It has been reported that some nonsense mutations result in the total absence or greatly reduced amounts of $V D R$ mRNA [25], but northern blot analysis has shown a normal amount of $V D R$ mRNA in patients with R30X mutations [18]. We confirmed the presence of $V D R$ mRNA in our patient by RT-PCR and real-time PCR using total RNA extracted from peripheral blood. The stability of $V D R$ mRNA with a nonsense mutation seems to depend on its location, and R30X in the VDR gene may escape mRNA decay.

The VDR-vitamin D system plays an important role in osteoclastogenesis. In vitro analyses have shown that $1,25(\mathrm{OH})_{2} \mathrm{D}$ stimulates RANKL expression through VDR in osteoblastic cells, which in turn increases osteoclastogenesis [26]. However, co-cultures of osteoblasts and osteoclast progenitors from $V D R$-null mice demonstrated that other factors, such 
as PTH and IL-1 alopha, could stimulate RANKL expression in the absence of a functional VDR-vitamin D system [27]. Therefore, we hypothesize that the high turnover bone phenotype of our patient at referral was a result of excessive RANKL activation caused by secondary hyperparathyroidism. Interestingly, the VDR-vitamin D system seems to be essential in post-natal hair cycling [28]. Alopecia is reported in some patients with VDDR2A, especially those with deleterious mutations, but not in patients with vitamin D-dependent rickets type 1 , which is caused by $25(\mathrm{OH}) \mathrm{D}$ 1-alpha-hydroxylase deficiency [29, 30]. The exact mechanism of alopecia in $V D R$-null mice and patients with VDDR2A is not clear, but previous studies have suggested ligand-independent actions of VDR in skin, which may involve the canonical Wnt signaling pathway [31].

Serum FGF23 levels in our patient were consistently below the limit of detection, and her serum phosphate levels fluctuated around the lower limit of the reference range. A previous study of a patient with R73X mutation also showed suppressed levels of serum FGF23 [22]. Thus, we hypothesize that the hypophosphatemia in our patient is not FGF23-related and is instead a result of decreased intestinal absorption and decreased renal tubular reabsorption of phosphate, caused by a lack of $1,25(\mathrm{OH})_{2} \mathrm{D}$ responsiveness and secondary hyperparathyroidism, respectively. Since her serum phosphate levels and TmP/GFR changed in parallel, $\mathrm{PTH}$, which is a negative regulator of $\mathrm{TmP} /$ GFR, seems to be the major determinant of serum phosphate levels in our patient (Fig. 3). Considering the fact that $V D R$-null mice also displayed undetectable FGF23 levels $\left[32,33\right.$, and $1,25(\mathrm{OH})_{2} \mathrm{D}$ stimulats FGF23 expression [34-36], the VDR-vitamin D system definitively plays an important role in FGF23 regulation. It has been shown that $F G F 23$-null mice display hyperphosphatemia, hypercalcemia, elevated serum $1,25(\mathrm{OH})_{2} \mathrm{D}$, and vascular calcification of the kidneys [37]. However, double-mutant mice lacking both FGF23 and VDR were normophosphatemic, normocalcemic, and showed no ectopic calcifications when fed a high calcium diet [38]. Therefore, adverse effects of FGF23-deficiency are primarily caused by excessive actions of $1,25(\mathrm{OH})_{2} \mathrm{D}$, which we do not expect to occur in patients with VDDR2A.

In vitro studies suggest that VDR downregulates the transcription of renin by binding to the promoter region of the REN gene, and studies using $V D R$-null mice and 1-alpha-hydroxylase-deficient mice show high plasma renin activity and increased renal renin mRNA $[39,40]$. Moreover, cardiac hypertrophy and fibrosis were detected in $V D R$-null mice regardless of coexisting hypertension [41]. A previous analysis of seventeen patients with VDDR2A aged 6 to 36 years showed normal renin activity and aldosterone levels, without hypertension or gross heart abnormalities [42]. These patients had mutations in the VDR gene that caused alopecia; fifteen of them had a nonsense mutation in exon 8 (Y295X), and two of them had a missense mutation in exon 2 (G33D) [42]. Further studies are necessary to clarify the regulation of the renin-angiotensin-aldosterone system in patients with VDDR2A. Until then, we will closely monitor for future cardiovascular complications in our patient although she is currently normotensive and does not have cardiac hypertrophy.

There are two limitations of our study. First, we were unable to perform genetic analysis of the patient's parents. Therefore, we could not rule out the possibility of uniparental disomy of chromosome 12, which has been reported in a previous case [22]. However, the fact that her parents are second cousins favors the presence of a homozygous R30X mutation. Second, very low serum $25(\mathrm{OH}) \mathrm{D}$ levels at referral raises the possibility of concurrent vitamin D deficiency. While VDR is considered to be essential for $1,25(\mathrm{OH})_{2} \mathrm{D}$ to exert most of its functions, VDR-independent $1,25(\mathrm{OH})_{2} \mathrm{D}$ actions, such as anti-proliferative effects in tumor cells, have been reported [43]. Therefore, we could not rule out the possibility that vitamin D deficiency might adversely affect the patient's bone metabolism in a VDR-independent manner. It has been shown that the CYP27B1 gene encoding 25(OH)D 1-alpha-hydroxylase was downregulated by VDR and upregulated by PTH $[12,44]$. Therefore, increased 25(OH)D 1-alpha-hydroxylase activity may result in increased conversion from $25(\mathrm{OH})$ $\mathrm{D}$ to $1,25(\mathrm{OH})_{2} \mathrm{D}$ and subsequently lower $25(\mathrm{OH}) \mathrm{D}$ levels in patients with VDDR2A, regardless of their vitamin D status.

In conclusion, we describe a patient with VDDR2A who developed secondary hyperparathyroidism and high bone turnover in adulthood. Although the R30X mutation found in this case resulted in a severely truncated VDR protein, sufficient amounts of oral calcium supplementation ameliorated her secondary hyperparathyroidism and nearly normalized her bone metabolic parameters. 


\section{Disclosure}

None of the authors have any potential conflicts of interest associated with this research.

\section{Acknowledgements}

This work was supported by Grants-in-Aid for Scientific Research from Japan Society for the Promotion of Science.

\section{References}

1. Francis RM, Selby PL (1997) Osteomalacia. Baillieres Clin Endocrinol Metab 11: 145-163.

2. Elidrissy AT (2016) The Return of Congenital Rickets, Are We Missing Occult Cases? Calcif Tissue Int 99: 227-236.

3. Munns CF, Shaw N, Kiely M, Specker BL, Thacher TD, et al. (2016) Global Consensus Recommendations on Prevention and Management of Nutritional Rickets. $J$ Clin Endocrinol Metab 101: 394-415.

4. Malloy PJ, Feldman D (2010) Genetic disorders and defects in vitamin d action. Endocrinol Metab Clin North Am 39: 333-346.

5. Goldsweig BK, CarpenterTO(2015)Hypophosphatemic rickets: lessons from disrupted FGF23 control of phosphorus homeostasis. Curr Osteoporos Rep 13: 88-97.

6. Hughes MR, Malloy PJ, Kieback DG, Kesterson RA, Pike JW, et al. (1988) Point mutations in the human vitamin D receptor gene associated with hypocalcemic rickets. Science 242: 1702-1705.

7. Malloy PJ, Tasic V, Taha D, Tutunculer F, Ying GS, et al. (2014) Vitamin D receptor mutations in patients with hereditary 1,25-dihydroxyvitamin D-resistant rickets. Mol Genet Metab 111: 33-40.

8. Haussler MR (1986) Vitamin D receptors: nature and function. Annu Rev Nutr 6: 527-562.

9. Bouillon R, Carmeliet G, Verlinden L, van Etten E, Verstuyf A, et al. (2008) Vitamin D and human health: lessons from vitamin D receptor null mice. Endocr Rev 29: 726-776

10. Christakos S, Dhawan P, Verstuyf A, Verlinden L, Carmeliet G (2016) Vitamin D: Metabolism, Molecular Mechanism of Action, and Pleiotropic Effects. Physiol Rev 96: 365-408.

11. Kim MS, Fujiki R, Murayama A, Kitagawa H, Yamaoka $\mathrm{K}$, et al. (2007) 1Alpha, $25(\mathrm{OH})_{2} \mathrm{D}_{3}$-induced transrepression by vitamin $\mathrm{D}$ receptor through E-box-type elements in the human parathyroid hormone gene promoter. Mol Endocrinol 21: 334-342.

12. Murayama A, Takeyama K, Kitanaka S, Kodera Y, Hosoya T, et al. (1998) The promoter of the human 25-hydroxyvitamin $\mathrm{D}_{3} 1$ alpha-hydroxylase gene confers positive and negative responsiveness to $\mathrm{PTH}$, calcitonin, and 1 alpha, $25(\mathrm{OH})_{2} \mathrm{D}_{3}$. Biochem Biophys Res Commun 249: 11-16.
13. Malloy PJ, Feldman D (2011) The role of vitamin D receptor mutations in the development of alopecia. Mol Cell Endocrinol 347: 90-96.

14. Marx SJ, Bliziotes MM, Nanes M (1986) Analysis of the relation between alopecia and resistance to 1,25-dihydroxyvitamin D. Clin Endocrinol (Oxf) 25: 373-381.

15. Li YC, Amling M, Pirro AE, Priemel M, Meuse J, et al. (1998) Normalization of mineral ion homeostasis by dietary means prevents hyperparathyroidism, rickets, and osteomalacia, but not alopecia in vitamin D receptor-ablated mice. Endocrinology 139: 4391-4396.

16. Yamazaki Y, Okazaki R, Shibata M, Hasegawa Y, Sato $\mathrm{K}$, et al. (2002) Increased circulatory level of biologically active full-length FGF-23 in patients with hypophosphatemic rickets/osteomalacia. J Clin Endocrinol Metab 87: 4957-4960.

17. Mechica JB, Leite MO, Mendonca BB, Frazzatto ES, Borelli A, et al. (1997) A novel nonsense mutation in the first zinc finger of the vitamin D receptor causing hereditary 1,25-dihydroxyvitamin $\mathrm{D}_{3}$-resistant rickets. J Clin Endocrinol Metab 82: 3892-3894.

18. Zhu W, Malloy PJ, Delvin E, Chabot G, Feldman D (1998) Hereditary 1,25-dihydroxyvitamin D-resistant rickets due to an opal mutation causing premature termination of the vitamin D receptor. J Bone Miner Res 13: $259-264$.

19. Zhou Y, Wang J, Malloy PJ, Dolezel Z, Feldman D (2009) Compound heterozygous mutations in the vitamin D receptor in a patient with hereditary 1,25-dihydroxyvitamin D-resistant rickets with alopecia. $J$ Bone Miner Res 24: 643-651.

20. Amling M, Priemel M, Holzmann T, Chapin K, Rueger JM, et al. (1999) Rescue of the skeletal phenotype of vitamin D receptor-ablated mice in the setting of normal mineral ion homeostasis: formal histomorphometric and biomechanical analyses. Endocrinology 140: 4982-4987.

21. Hoenderop JG, Nilius B, Bindels RJ (2005) Calcium absorption across epithelia. Physiol Rev 85: 373-422.

22. Tamura M, Isojima $T$, Kawashima M, Yoshida $H$, Yamamoto K, et al. (2015) Detection of Hereditary 1,25-Hydroxyvitamin D-Resistant Rickets Caused by Uniparental Disomy of Chromosome 12 Using Genome-Wide Single Nucleotide Polymorphism Array. PLoS One 10: e0131157. 
23. Li YC, Bolt MJ, Cao LP, Sitrin MD (2001) Effects of vitamin $\mathrm{D}$ receptor inactivation on the expression of calbindins and calcium metabolism. Am J Physiol Endocrinol Metab 281: E558-564.

24. Friedman PA (2000) Mechanisms of renal calcium transport. Exp Nephrol 8: 343-350.

25. Malloy PJ, Hochberg Z, Tiosano D, Pike JW, Hughes MR, et al. (1990) The molecular basis of hereditary 1,25-dihydroxyvitamin $\mathrm{D}_{3}$ resistant rickets in seven related families. J Clin Invest 86: 2071-2079.

26. Suda T, Takahashi N, Udagawa N, Jimi E, Gillespie MT, et al. (1999) Modulation of osteoclast differentiation and function by the new members of the tumor necrosis factor receptor and ligand families. Endocr Rev 20: 345-357.

27. Takeda S, Yoshizawa T, Nagai Y, Yamato H, Fukumoto S, et al. (1999) Stimulation of osteoclast formation by 1,25-dihydroxyvitamin $\mathrm{D}$ requires its binding to vitamin D receptor (VDR) in osteoblastic cells: studies using VDR knockout mice. Endocrinology 140: 1005-1008.

28. Sakai Y, Demay MB (2000) Evaluation of keratinocyte proliferation and differentiation in vitamin $\mathrm{D}$ receptor knockout mice. Endocrinology 141: 2043-2049.

29. Dardenne O, Prud'homme J, Arabian A, Glorieux FH, St-Arnaud R (2001) Targeted inactivation of the 25-hydroxyvitamin D(3)-1(alpha)-hydroxylase gene (CYP27B1) creates an animal model of pseudovitamin D-deficiency rickets. Endocrinology 142: 3135-3141.

30. Panda DK, Miao D, Tremblay ML, Siois J, Farookhi R, et al. (2001) Targeted ablation of the 25-hydroxyvitamin D 1alpha -hydroxylase enzyme: evidence for skeletal, reproductive, and immune dysfunction. Proc Natl Acad Sci U S A 98: 7498-7503.

31. Lo Celso C, Prowse DM, Watt FM (2004) Transient activation of beta-catenin signalling in adult mouse epidermis is sufficient to induce new hair follicles but continuous activation is required to maintain hair follicle tumours. Development 131: 1787-1799.

32. Shimada T, Yamazaki Y, Takahashi $\mathrm{M}$, hasegawa $\mathrm{H}$, Urakawa I, et al. (2005) Vitamin D receptor-independent FGF23 actions in regulating phosphate and vitamin D metabolism. Am J Physiol Renal Physiol 289: 1088-1095.

33. Yu X, Sabbagh Y, Davis SI, Demay MB, White KE (2005) Genetic dissection of phosphate- and vitamin D-mediated regulation of circulating Fgf23 concentrations. Bone 36: 971-977.

34. Kolek OI, Hines ER, Jones MD, LeSueur LK, Lipko $\mathrm{MA}$, et al. (2005) 1alpha,25-Dihydroxyvitamin $\mathrm{D}_{3}$ upregulates FGF23 gene expression in bone: the final link in a renal-gastrointestinal-skeletal axis that controls phosphate transport. Am J Physiol Gastrointest Liver Physiol 289: G1036-1042.

35. Yamamoto R, Minamizaki T, Yoshiko Y, Yoshioka H, Tanne K, et al. (2010) 1alpha,25-dihydroxyvitamin $\mathrm{D}_{3}$ acts predominately in mature osteoblasts under conditions of high extracellular phosphate to increase fibroblast growth factor 23 production in vitro. $J$ Endocrinol 206: 279-286.

36. Saito H, Maeda A, Ohtomo S, Hirata M, Kusano K, et al. (2005) Circulating FGF-23 is regulated by 1alpha,25dihydroxyvitamin $\mathrm{D}_{3}$ and phosphorus in vivo. $J$ Biol Chem 280: 2543-2549.

37. Shimada T, Kakitani M, Yamazaki Y, Hasegawa H, Takeuchi Y, et al. (2004) Targeted ablation of Fgf23 demonstrates an essential physiological role of FGF23 in phosphate and vitamin D metabolism. J Clin Invest 113: 561-568.

38. Hesse M, Frohlich LF, Zeitz U, Lanske B, Erben RG (2007) Ablation of vitamin D signaling rescues bone, mineral, and glucose homeostasis in Fgf-23 deficient mice. Matrix Biol 26: 75-84.

39. Li YC, Kong J, Wei M, Chen ZF, Liu SQ, et al. (2002) 1,25-Dihydroxyvitamin $\mathrm{D}(3)$ is a negative endocrine regulator of the renin-angiotensin system. $J$ Clin Invest 110: 229-238.

40. Zhou C, Lu F, Cao K, Xu D, Goltzman D, et al. (2008) Calcium-independent and $1,25(\mathrm{OH})_{2} \mathrm{D}_{3}$-dependent regulation of the renin-angiotensin system in 1alphahydroxylase knockout mice. Kidney Int 74: 170-179.

41. Simpson RU, Hershey SH, Nibbelink KA (2007) Characterization of heart size and blood pressure in the vitamin D receptor knockout mouse. J Steroid Biochem Mol Biol 103: 521-524.

42. Tiosano D, Schwartz Y, Braver Y, Hadash A, Gepstein $\mathrm{V}$, et al. (2011) The renin-angiotensin system, blood pressure, and heart structure in patients with hereditary vitamin D-resistance rickets (HVDDR). $J$ Bone Miner Res 26: 2252-2260.

43. Costa JL, Eijk PP, van de Wiel MA, ten Berge D, Schmitt F, et al. (2009) Anti-proliferative action of vitamin D in MCF7 is still active after siRNA-VDR knockdown. BMC Genomics 10: 499.

44. Brenza HL, Kimmel-Jehan C, Jehan F, Shinki T, Wakino S, et al. (1998) Parathyroid hormone activation of the 25-hydroxyvitamin $\mathrm{D}_{3}$-1alpha-hydroxylase gene promoter. Proc Natl Acad Sci U S A 95: 1387-1391. 